\title{
Konfrontasas Jumal: \\ The Role of Community Characters in Sending Cases of Sexual Violence against Children
}

\author{
Ernita Dewi ${ }^{1}$, Said Amirulkamar ${ }^{2}$ \\ ${ }^{1}$ Faculty of Ushuluddin and Philosophy, Universitas Islam Negeri Ar-Raniry, Indonesia \\ ${ }^{2}$ Faculty of Social Science and Political Science Universitas Islam Negeri Ar-Raniry, Indonesia \\ ernita.dewi@ar-raniry.ac.id, said.amirulkamar@ar-raniry.ac.id
}

\section{Abstract}

The changing times that are getting faster with the presence of communication technology have shifted many positive trasidies in society, turning into a new tradition that is more individualistic. One of them is the change in social institutions, community leaders, in Acehnese society, which can be said to be one of the local wisdoms. Social institutions consisting of village officials have the duty to protect, guard, supervise and resolve all problems that occur in the community. They are like a gampong fence that continues to protect society from all forms of crime and a-moral action, one of which is sexual violence against children and women. The rise in cases of sexual violence must be addressed, one of which is by optimizing the role of community leaders.
Keywords

community leaders, sexual vidence; women; children

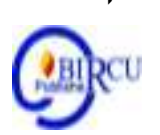

\section{Introduction}

The Aceh public was shocked by the media coverage of the arrest of three pairs of teenagers including minors who were caught having sex parties. It's even more sad that the kid has tree some intimate relationships. Not only is the problem of promiscuity that is very worrying, cases of sexual violence against children, are also increasing in 2020. This reality has shaken Acehnese people who are accustomed to living with a religious atmosphere, especially this region with special autonomy which runs Islamic Sharia. The Covid-19 pandemic has brought significant changes to the lifestyle of teenagers. The use of internet media and the freedom of children to use cell phones allegedly triggered the tendency of adolescents to commit obscene acts such as promiscuity between boys and

girls. Children in both rural and urban areas.

Aceh has a community supervisory power that relies on traditional leaders, this is called pageu gampong, in addition to the important role of both children's parents. The membership of the pageu gampong consists of village heads (keuchik), village secretaries, hamlet heads, religious leaders, and members of tuha peut, or so-called members of the village level parliament. This power can actually provide tight control so that the movement of youth activities that lead to violations of Islamic Sharia or immoral acts, both in the field of promiscuity, drugs and other crimes can be emitted as early as possible. However, the number of cases that add to the black list of conditions of free sex, sexual violence, rape has not been eliminated. As if there is a broken link in terms of supervision,

It is interesting to trace the role of society in this pandemic era, to what extent this supervision can be provided, or are all parties ignorant of the development of fate of younger generation in the future, or are there more serious problems that must be resolved, so that problems related to promiscuity and sexual violence goes unnoticed. If this happens, it is very important to reinforce the role of the gampong apartment again with serious attention from the regional government, along with its apparatus down to the smallest level at the village level. 
Konfrontasi Journal: Culture, Economy and Social Changes, 7 (4) December 2020, 343-350

ISSN: 1410-881X (Print), 2716-2095 (Online)

M Ernita Dewi, Said Amirulkamar: The Role of Community Characters in Sending Cases of Sexual Violence against Children

DOI: https://doi.org/10.33258/konfrontasi2.v7i4.132

http://www.konfrontasi.net/index.php/konfrontasi2

\section{Review of Literatures}

\section{Study of the Role of Community Figures (Social Institution: Pageu Gampong)}

Reality phenomenon found in the community, the perpetrators of indigenous elderly is dwindling, the process of inheritance naturally did not go as expected, the younger generation is not interested in doing customary activities, tedious time consuming ceremonial, indigenous language recurrent and over the times, the ceremony began to be simplified, because of financial factor (Amri, 2018)

There are many studies on social institutions in other areas outside Aceh, one of which is research conducted by Novri Susan with the title The Role of Adat Institutions in Preventing / Stopping Conflict between Communities. This research tries to place customary institutions as a solution in dealing with various social conflicts. However, it also tries to classify social problems or conflicts, the handling of which can involve customary institutions or customary courts.

Then, research by Nurul Hasmy Mallalahi entitled Social Institutions for the Protection of Neglected Children at the Bambu Apus Child Social Protection House (Rpsa). This study discusses the Bambu Apus Children's Social Protection House (RPSA) as a new social institution in urban communities for the protection of neglected children. The study was conducted using a descriptive qualitative research approach, through the methods of collecting observational data, interviews, and literature study. The results showed that while serving neglected children in a safe house, RPSA Bambu Apus replaced the function of family, household and in-service arrangements in meeting daily needs and child care, so that the child was returned to a permanent care environment that fulfilled the child's best interests.

Furthermore, the research entitled Protection of Women and Children of Trafficking Victims in Kapuas Hulu Regency by Siti Hariati Sastriyani. This research is included in the qualitative research group with the research population being Kapuas Hulu District. The sample that was deliberately taken was the District of Badau because in the District of Badau there was already a Cross-Border Post in Nanga Badau. This city becomes traffic because it is located in the border area with Malaysia. This activity is designed to determine the potential, dynamics and participatory planning framework to see the factors behind trafficking problems in the area and also to identify alternative solutions to problems desired by the participants.

Haryati Roebyantho \& Ety Padmiati's research, in a study entitled Empowerment of Social Institution Networks in Strengthening Community Social Resilience in South Sumatra Province. This research, which is focused on the South Sumatra region, aims to obtain an overview of how the implementation of empowerment of social institutions networks in strengthening social resilience of the community, and how the role and function of social infrastructure networks. The method used is semi-experimental, namely giving several treatments to the selected institutions as the experimental / treatment group with requirements. Determination of the treatment group purposively on the basis of social principles that have had cooperation in dealing with social welfare problems.

The concept of Empowerment and enrichment in the world of work is very much needed, because employees who work are human beings who have a sense, creativity and initiative as a manifestation of their human elements, so that there are employees who are very ambitious, totality, visoiner, need for achievement. Conversely, there are employees who are not ambitious, have no initiative, low work ethic, low work skills, or who have been in a certain position for too long, so that the employee becomes unproductive or novice employees who do not have enough experience. For such employees, empowerment and 
enrichment efforts are needed so that the world of work or the organization runs according to the vision and mission of the institution. (Abida, 2020)

Nofika Chilmiati and RB Sularto in his research entitled Advocacy Policy Against Women and Children Based on Protection of Victims of Violence. This study aims to discuss advocacy policies for women and children in accordance with the principles of protection for victims of violence. Another objective is the policy to protect victims of violence against women and children in the future. The approach method used in this research is a sociological juridical approach

\section{Discussion}

\subsection{The Phenomenon of Violence against Women and Children}

Talking about violence against women and children has become a world phenomenon, not only in Aceh. WHO studies in various countries in the world show that at least 1 in 4 women admit to having experienced physical violence or sexual violence, or both from an intimate partner throughout their life. Physical and / or sexual violence perpetrated by this couple is also followed by the control of behavior towards the victim. Meanwhile, population-based studies conducted on men in Asia-Pacific show that $26 \%$ to $80 \%$ of men admit to having committed physical and / or sexual violence against their partners.

In Indonesia alone, based on various population-based studies that have been available, it is estimated that $25 \%$ to $59 \%$ of women who have been married or have a partner have experienced physical and / or sexual violence by their partners. The IMAGES (International Men and Gender Equality Survey) survey of more than 2,500 men conducted in three regions in Indonesia, Jakarta, Purworejo and Jayapura in 2012/2013 showed that 25.7\% $-60.2 \%$ of men admitted to having committed physical violence and / or sexual partners with intimate female partners.

The report of the National Commission on Violence against Women (KomnasPerempuan) compiled from various service institutions in Indonesia from 2001 to 2012 recorded a total of 3,169 to 216,156 cases of VAW every year with a tendency for the number to increase from year to year, as seen in Figure 1. Most or more than $90 \%$ of cases of VAW occur in the scope of household or personal relations (KDRT / RP), and the rest are non-KDRT / RP cases, namely VAW cases that occur in the community or state domain.

No less heartbreaking fact, when reports of violence against children emerged, these cases were dominated by cases of sexual abuse. Children often become targets for sexual harassment, because at this age the child can easily be influenced and threatened by the perpetrator. The percentage of sexual harassment currently occurring is increasing, as is the case in Aceh. The Aceh Children's Legal Aid Institute (LBH) recorded 149 cases of sexual violence / abuse against children in Aceh that occurred during 2010 to 2014. Cases of sexual violence / abuse against children in Aceh increased every year where in 2010, 27 cases; in 2011, 29 cases; 2012, 32 cases; in 201326 cases and in 2014 recorded 35 cases. According to Rudy Bastian, the increase in this case due to lack of concern and prevention by the government.

Psychological conditions that can result from sexual harassment and violence such as anger, annoyance, shame and so on. In 2014, UNICEF reported that one in ten girls was sexually abused. This data may not be fully conclusive, because sexual harassment makes the person who is being harassed uncomfortable without suffering serious physical pain so that a lot of sexual abuse is still not reported. Therefore, harassment behavior is not well recorded, 
both in legal institutions and in social institutions. However, if this continues, it will result in unsafe and uncomfortable community life.

Throughout 2020, there were 200 cases of violence against children and 179 cases of violence against women in Aceh, "said Riswati, Director of the NGO Flower Aceh. Said Riswati, there were 3 highest forms of violence experienced by children in Aceh, this was conveyed by the Integrated Service Center for the Empowerment of Women and Children (P2TP2A) Aceh, namely 69 cases of sexual harassment, 58 cases of psychological violence, and 33 cases of rape. Meanwhile, violence against women in the form of sexual harassment was recorded as 17 cases, 9 cases of rape, 112 cases of domestic violence, 90 cases of psychological violence, and 55 cases of physical violence. "The rest is in the form of economic neglect and others," said Riswati. The total cases of violence against women and children in Aceh as of June 2020, were 379 cases. Previously recorded violence data, in 2019 there were 1,044 cases,

Furthermore, the Director of LBH Apik Aceh, Roslina Rasyid, said there were various obstacles in dealing with sexual violence against children in Aceh. One of them is related to policy dualism in handling sexual violence. The rules used to handle cases of sexual violence against children, especially those aged 14 years and over, still use the Jinayah Qanun, which punishes perpetrators with whips, not imprisonment. Despite the enactment of the qanun, the impact of the resulting policy is considered to only provide a temporary deterrent effect to the perpetrator, but not the psychological trauma experienced by the victim.

The Banda Aceh Police Satreskim announced that cases of violence and sexual abuse against children had increased during 2020. Generally, the perpetrators were the closest people to the victim, ranging from the uncle, stepfather to close neighbors. There is even a case involving his own father. Kasat Reskrim POlresta Banda Aceh, AKP Muhammad Ryan Citra Yudha, said that in 2020 his party handled 32 cases related to children in Banda Aceh. The number has increased compared to the previous year as many as 21 cases.

Referring to Aceh, the phenomenon of violence against women and children is increasing and increasing throughout the year. The facts that have been revealed to the public one by one show that many of these cases have become veiled because they do not dare to be disclosed to the public, more so that the victims of girls do not dare to reveal the suffering they have experienced to their parents. Some of the cases that were exposed to the public were as follows, because accidentally there were signs that led to sexual violence against children.

This child molestation case was revealed when a mother wanted to find a household assistant, when the woman came with her husband to the girl's house, the child's face was frightened and refused to attend the household assistant. After being investigated, it turned out that the woman's husband had molested her daughter, and not only the girl, there were two other girls who were raped on the same day. The incident was revealed after several months, because the child did not want to tell his mother about the case he had experienced.

Reflecting on the high number of cases of abuse, rape of children, the police urge parents to be able to control and supervise children's relationships strictly. Don't trust anyone easily, because many cases of violence against children actually occur from close people and even from their own families. Parents should be worried that when their children are not at home, at least every 10 minutes, parents can monitor their children's movements.

Deputy Chairperson of the PKK Driving Team, Dyah Erti Idawati, admitted that she was concerned about the high rate of violence against children. It needs to be given strict and legal sanctions that are appropriate to the perpetrator Violence experienced by children felt that it could not be suppressed because this case was repeated even though someone had been 
convicted. From Dyah's comments, it can be seen that heavier penalties must be given, so that the perpetrators are afraid to repeat their actions. It is also important to be an important lesson for new actors who want to repeat the crime. If the sentence given is very small, it is feared that it will have an impact on the recurrence of the same case with more victims in the future.

Chairman of the Syar'iyah Court Jantho, Siti Salwa SHI, MH through his public relations Tgk Murthada Lc who was contacted by the media, Wednesday, December 23, 2020, said that the jinayat case in Aceh Besar increased during the Covid 19 pandemic, compared to 2019. In 2020 cases of rape dominate the cases tried in 2020, as many as 8 case s of rape. In 2020, there were 5 cases that caught the attention of the public, 3 cases of rape in two cases by the mahram, namely the accused's father and uncle as the perpetrator.

\subsection{The Role of Pageu Gampong in Eliminating Sexual Violence and Promiscuity}

In Aceh, social institutions are known as pageu gampong. The role of social institutions is very large in supervising society so that they do not do things that are contrary to the prevailing norms in society. However, along with the times, the role of social institutions in Aceh is decreasing, even though there is a Qanun (Perda) that regulates this matter. Based on the importance of the role of social institutions, but it has not been able to be optimized due to collisions with the attitude of the community that has begun to ignore the role of community leaders. This study seeks to obtain concrete answers to this problem, in particular to strengthen the role of social institutions to become a protective shield for the safety of women and children.

Chaizir, a community leader in one of the villages in the District of Want Jaya, Aceh Besar, said that parents are now different from old people. If in the past parents said "that my child is your child too, let's watch it together". Now on the contrary, parents will be very angry if their children are reprimanded by community leaders for doing things that are not right. In the name of human rights and freedom, it is not uncommon for parents to strike back at community leaders who have the desire to reprimand the behavior of a child who has deviated from the truth.

As a community leader Chaizir remains committed to always ensuring that teenagers in his village do not commit acts that violate Islamic law and commit acts that lead to adultery. If a teenager is found alone with a man who is not his mahram, then his parents will reprimand and call him. Advice was given not to be alone with men in the house or in quiet places. Young women who come home late at night with their boyfriends will also be given good advice so as not to repeat their actions.

The village youths together with Chaizir always carry out strict supervision of the community, and immediately detect any deviations in community life in the village. So far, there have not been any cases as reported by the media, this is because village officials are always present to provide supervision to the community. In terms of giving warnings and supervision, one must also be careful, according to Chaizir, if one is wrong in handling a problem, it could be that the problem is turned in the direction of the party who wants to solve it. Now it is very difficult to solve a problem, people can accuse the reporting party who is the perpetrator, so be careful.

Chaizir gave one example, an old man who had a couple of underage teenagers dating in a public toilet in a village. Then this man rebuked the teenage couple, the boy ran away because he was afraid, while the woman stayed in the toilet. This old man told the young woman that her actions would be reported to her parents and community leaders. Then this girl reported to her mother that the old man had abused her. The elderly man's subsequent actions were reported to the police and received a prison sentence for allegedly molesting a 
minor. Even though this old man swore not to commit this act of sexual immorality. Society has great faith in this old man, because the daily life of the man is a good society and has never done anything despicable. However, whether the power of the young woman's testimony is considered valid, and a long sentence awaits her.

This incident made residents very worried if they wanted to report matters related to the promiscuity of underage adolescents, they were afraid that reports would attack people who wanted to solve the case they saw. Therefore Chaizir and other village officials were very careful when monitoring and reporting cases that occurred. Usually, not only one person sees it, there must be several witnesses so that the reported case is more accurate, and the perpetrator cannot fight back by attacking the reporter.

The role played by Chaizir as a community leader is a form of protection for residents, especially women and children. This is a local wisdom in Aceh called Pageu Gampong (Pagar Desa). The presence of village officials is very much needed, especially in the present era, where people are increasingly affected by the free life which is triggered by the presence of the internet.

Khalid, one of the village heads in the Aceh Besar district, also stated that the condition of the community now is different from the previous community. In the era of information openness and the development of communication technology, society has changed considerably in their thinking. They have their own opinion and the greatest influence of digital communication media is felt. Access to pornographic content is a driving factor in the emergence of various sexual violence against women and children, as well as the promiscuity of young boys and girls. Responding to this situation, village officials could not do much, because their function was only to provide socialization, guard and supervise community activities in the village. To go too far in people's life certainly cannot,

Khalid said that society is now very closed with the cases experienced by their families, so it has never been conveyed to the community leaders. This condition makes a crime so that it lasts a long time and cannot be resolved. Maybe because of the embarrassment factor, it is usually reported if it is no longer able to be buried by yourself, or the case has spread and is known by many people. As a community leader, Khalid is ready to protect and supervise his community, so that he can avoid all criminal acts. But if people do not want to be open and choose to remain silent, the village apparatus cannot do anything about it.

Khalid hopes that the community can give a wider role to village apartments in an effort to provide protection to the community, especially women and children. However, the village must be the initial milestone in solving the problem, and must be the closest supervisor to detect so that cases of child abuse do not occur. Reflecting on the cases of sexual violence against children that often occur today, Khalid appealed to the public to be more open to reporting strange things found around them, so that cases of sexual violence can be eliminated as early as possible.

Nasrul also mentioned that the presence of village officials in providing supervision and protection for residents is very important. During the Covid-19 pandemic, Nasrul admitted that many cases were reported by residents to the Civil Service Police Unit and Wilayatul Hisbah Aceh (Satpol PP and WH). One of the cases reported and secured by residents was the case of an intimate relationship between a man and a 14 year old girl. Besides this intimate relationship, drug cases were also found, in which the couple used drugs of the type of shabu-shabu. This case was reported by the residents, because the residents were very anxious about the couple's behavior. It has been almost a few nights, the couple is staying in an empty shop house. Every night the men bring underage teenagers to the place and they have premarital sexual intercourse. The community became angry and arrested the 
couple and then reported them to the Aceh Satpol PP and WH offices to be processed according to the applicable law.

The participation of the gampong apparatus is needed so that all crimes and violations against Islamic law can be overcome. The community and gampong apparatus are very close to the cases that have occurred. If it opens the village apparatus who acts to supervise it, then who else will supervise it? Village officials who know best about the condition of their residents can see the movements and activities of the residents at any time. If anything suspicious is found, it must be immediately addressed and resolved so that there are no victims, especially women and children.

\subsection{Cover}

Optimizing the role of community leaders is one of the imperatives based on the reality of the high rate of sexual violence in Aceh, and the bad influence of pornography on the emergence of premarital sex among adolescents. The community must give a large portion to village apartments in order to prevent the act of a- morals that often occur in society. All residents must build an open attitude, give trust to village officials so that they can help every problem they experience. Don't be shy about expressing a problem, because village officials clearly understand more about the things that happen in their village. If the community closes access to the involvement of village officials in monitoring and preventing all forms of criminality, it will be very difficult to reduce the number of violence including sexual violence against women and children. As one of the local wisdoms that must be maintained, the existence of pageu gampong (social institutions) really needs to be empowered, especially in the present era, when people are treated to various forms of technological development, which may not necessarily be absorbed by all people.

\section{Conclusion}

The changing times that are getting faster with the presence of communication technology have shifted many positive trasidies in society, turning into a new tradition that is more individualistic. One of them is the change in social institutions, community leaders, in Acehnese society, which can be said to be one of the local wisdoms. Social institutions consisting of village officials have the duty to protect, guard, supervise and resolve all problems that occur in the community. They are like a gampong fence that continues to protect society from all forms of crime and a-moral action, one of which is sexual violence against children and women. The rise in cases of sexual violence must be addressed, one of which is by optimizing the role of community leaders.

\section{References}

Abida, et al. (2020). Empowerment and Enrichment Principles in the Philosophy of Pucuk Rebung Motives of Karawang Gayo. Budapest International Research and Critics Institute-Journal (BIRCI-Journal). P. 3912-3922.

Ahmad Humam Hamid, Data Analysis in Social Sciences Research, Paper on research training in Social Sciences, (Research Center for Socio-Cultural Sciences, DarussalamBanda Aceh, 1997).

Amri, Y. (2018). Mangupa; An Oral Tradition of Angkola Community. Budapest International Research and Critics Institute-Journal (BIRCI-Journal). P.51-61. 
Arimbi Heroepoetri (ed.), Legal Knowledge for Women's Legal Empowerment: Results of Monitoring Women's Access to Justice, (Jakarta: Komnas Perempuan, 2011).

Claudia Gracia-Moreno, WHO Multi-country Study on Women's Health and Domestic Violence agains Women: Initial Results on Prevalence, Health Outcomes and Women's Responses, (WHO Press, Geneva, 2005).

Emma Fulu, Why Do Some Men Use Violence Against Women and How We Can Preveni It ?: Quantitative Finding From The United Nations Multi-Country Study on Men and Violence in Asia and The Pacific. (UNDP-UNFPA-UN Women and UNV, Bangkok, 2013).

Haryati Roebyantho and Ety Padmiati, "Empowerment of Social Institution Networks in Strengthening Community Social Resilience in South Sumatra Province", in the Journal of Social Welfare Research and Development, Vol. XII, No. 3, (2007).

Haryati Roebyantho and Ety Padmiati, "Empowerment of Social Institution Networks in Strengthening Community Social Resilience in South Sumatra Province", in the Journal of Social Welfare Research and Development, Vol. XII, No. 3, (2007).

Ihromi TO, Principles of Cultural Anthropology, (Jakarta: Yayasan Obor Indonesia, 1994).

Imron Arifin, Qualitative Research in Social and Religious Sciences, (Jakarta: Kalimasahada Press, 1996).

Koentjaraningrat, Introduction to Anthropology, Cet. VIII, (Jakarta: Rineka Cipta, 1990).

Komnas Perempuan, Realizing the Protection of Women Victims through the Fulfillment of Legal Aid: Position Paper on Discussion of the Legal Aid Bill.

Kristi Poerwandari, Violence Map: The Experience of Indonesian Women, (Komnas Perempuan, Jakarta, 2002).

Moh. Nazir, Research Methods, (Jakarta: Glialia Indonesia, 1985).

Mohammad Hakimi, Silence for the sake of Harmony, Violence Against Wives and Women's Health in Central Java, Indonesia. LPKGM FK UGM-Rifka Annisa WCC-Umea University-Women's Health Exchange, Yogyakarta, 2001).

Nofika Chilmiati and RB. Sularto, "Advocacy Policy Against Women and Children Based on Protection of Victims of Violence", in the Journal of Law Reform, Vol. IX, No. 2, (2014).

Novri Susan, Legal Assessment Report: The Role of Customary Institutions in Preventing or Stopping Inter-Community Conflict, (Jakarta: Research and Development Center for the National Legal System, National Law Development Agency, Ministry of Law and Human Rights, 2014).

Nurul Hasmy Mallalahi, Social Institution for the Protection of Abandoned Children at the Bambu Apus Child Social Protection House (Rpsa), (Social Anthropology Thesis, FISIPOL, University of Indonesia, 2012).

Parsuadi Suparlan, Human, Culture and Environment, (Jakarta: Rajawali Press, 1984).

Paulus Wirotomo, Construction of Social Institutions Network for Strengthening Social Resilience (Conceptual Framework), Expert Discussion Paper on Building Social Institutions Networks in Strengthening Community Social Resilience, (Jakarta: Center for Community Social Resilience Development. Balatbang Depsos RI, 2004).

Social Stewardship, (Faculty of Communication, Mercu Buana University, 2005).

Siti Hariati Sastriyani, "Protection of Women and Children Victims of Trafficking in Kapuas Hulu District", In the Marwah Journal, Vol. IX, No. 2, (2010).

Soerjono Soekanto, Sociology An Introduction, New Fourth Edition, (Jakarta: Raja Grafindo Persada, 1990).

Suharsimi Arikunto, Research Procedure: A Practical Approach, (Jakarta: Rineka Cipta, 1996).

Syaiful Bahri and Fajriani, "An Initial Study of the Levels of Sexual Harassment in Aceh", in the Enlightenment Journal, Vol. IX, No. 1, (2015). 